\section{Tomasz Rawski}

Institute of Sociology,

University of Warsaw
Katarzyna Roman

Institute of Russian Studies, University of Warsaw

\title{
How to Escape? The Trap of the Transition in the Recent Cinema of Bosnia and Herzegovina (2000-2012)
}

\begin{abstract}
The paper concerns the latest cinema of Bosnia and Herzegovina (2000-2012). Focusing on the cinema of social criticism (represented by movies which try to rethink the new socio-political order gradually emerging in $\mathrm{BiH}$ after the war of 1992-95), the authors recognize the Bosnian society as a community captured in the trap of an unfinished system transition.

The story of the Bosnian society, simultaneously stuck in a dysfunctional and oppressive state and completely devoid of any prospects for the improvement of this situation, seems to be dominated by several escape strategies into an alternative reality: the nostalgic past, the imagined present or the utopian future. In that sense, the Bosnian cinema of social criticism turns out to be a cinema of social escapism.
\end{abstract}

Key words: Bosnia and Herzegovina; Bosnian cinema; social escapism; postwar society

\section{Introduction}

T $t$ is not easy to talk about the present-day Bosnia and Herzegovina 1 (below abbr. as: $\mathrm{BiH}$ ) without the war in the background. Film artists continuously face the trauma of the first half of the 1990s and continue

\footnotetext{
This is an Open Access article distributed under the terms of the Creative Commons Attribution 3.0 PL License (creativecommons.org/licenses/by/3.0/pl/), which permits redistribution, commercial and non-commercial, provided that the article is properly cited. (C) The Author(s), 2014

Publisher: Institute of Slavic Studies, Polish Academy of Sciences

Editor in chief: Jolanta Sujecka

Conception and academic editing of this issue: Maciej Falski
} 
to enrich the war film genre with more pictures ${ }^{1}$. This subject certainly deserves a detailed study, the more so because the post-war BosnianHerzegovinian cinema (below abbr. as: bh. cinema ${ }^{2}$ ) has not actually had a critical reception (Ibrahimović 2008: 125). However, almost twenty years after signing the Dayton Peace Agreement, post-war $\mathrm{BiH}$ is still undergoing a long economic, social and political transformation that does not seem to be coming to an end in the near future. A closer look at the social reality of contemporary $\mathrm{BiH}$ is then particularly worth taking, the more so because social criticism seems to be the second most important issue in the bh. cinema. The filmmakers seem to make socially engaged films as often as they do war films.

In this paper, we focus on the recent bh. cinema from the years 20002012. One of the reasons is that, according to the film critics from the region, bh. cinema was literally dead until 2001 (Pavičić 2008: 651). We discuss films that make attempts to interpret the new social order, slowly emerging from the war storm. Therefore, we are less interested in film texts with the war in the foreground, nor are we interested in the ones where the main characters are still engrossed in the consequences of the war ${ }^{3}$. First of all, we take into account films that problematize the Bosnian "here and now", as well as those images in which the trauma of war affects the present life to a limited extent. We take a closer look at those films which, in our opinion, give the best account of the condition of contemporary $\mathrm{BiH}$ society.

When we speak of bh. cinema, we should keep in mind its internal division, one of the consequences of the administrative split of contemporary $\mathrm{BiH}^{4}$. In practice, this means that bh. cinema is dominated by Bosnian Muslims, since Bosnian Serbs practically do not make films ${ }^{5}$. Furthermore, bh. cinema is largely a Sarajevian cinema - the vast majority of the films take

\footnotetext{
1 The genre widely represented by such films as the famous No man's land (2001) directed by Danis Tanović, but also Remake (2003) by Dino Mustafić, Go West (2005) by Ahmed Imamović, Nafaka (2006) by Jasmin Duraković and others.

2 Bh. cinema and bh. film are the abbreviations often used by film critics from the region, such as Nedžad Ibrahimović and Jurica Pavičić.

3 So those movies in which the characters focus, above all, on searching for their deceased beloved ones (as in Belvedere (2010) by Ahmed Imamović), struggling for their decent burial (as in Halimin put (2012) directed by a Croat, Arsen A. Ostojić) or looking for lost biological parents (as in Ostavljeni (2010) by Adis Bakra).

4 Contemporary Bosnia and Herzegovina, by virtue of the Dayton Peace Agreement, is a federation of two, largely autonomous entities: The Federation of Bosnia and Herzegovina, with a Muslim-Croat majority, and Republika Srpska, with a Serb majority.

5 If Republika Srpska participates in the production of big-screen feature films, it is usually the second or subsequent producer, generally in co-production with Serbia (Turneja (2008) by Goran Marković, the Serbian director, can be a good example here); however, some Serbian actors, such as Dragan Bjelogrlić, usually take roles in the Federation films.
} 
place in the official capital of the country. The Bosnian province remains undervalued.

The recent bh. cinema tries to fill up the cultural void that emerged after the collapse of the relatively coherent Yugoslav symbolic universe, followed by the devastating civil war. According to Nedžad Ibrahimović, contemporary Bosnian artists feel deracinated - on the one hand not belonging to any film tradition, and unable to begin a new, relatively autonomous paradigm, on the other, under constant economic pressure and the necessity to reach a compromise between the desire to realize one's own artistic aspirations and the need to create such a film interpretation of the contemporary reality which would meet broad social expectations (Ibrahimović 2008: 117).

One of the characteristic features of the recent bh. cinema of social criticism seems to be a clear dichotomy between extremely serious social drama kept in a raw realistic convention and derisive popular comedy sliding into complete nonsense. Regardless of the consensus with popular cinema, all the discussed films are permeated by an uncompromising social criticism $^{6}$.

\section{Bosnia and Herzegovina is a dying country}

In the Bosnian vision of disordered transition, one of the least useful actors is the political elite. Above all, filmmakers criticize their hardly noticeable impact on improving the social situation, total passivity in the decision-making process and lack of any strategy of state management. In the eyes of Pjer Żalica, director of Gori vatra (Fuse, 2003), the government appears to be a comic puppet theatre, blindly subordinated to the patterns of Western democracy. According to the author, the most absurd situation takes place when the Bosnian authorities voluntarily waive all their competencies in exchange for a vague promise of immediate improvement. In Gori Vatra, representatives of the state administration, naively believing in the redemptive power of the planned visit of the President of the United States, passively submit to the decisions of the U.S. delegation, who degrade them to the role of cultural animators. The final failure of the entire project, interrupted by the suicide of the former police chief, reveals that the inert local authorities are not able to see the real social problems.

6 The general remark worth noticing here, is that one of the greatest achievements in the history of Yugoslav cinema is strictly connected to social criticism - the films of crni talas, crni val (Eng. black wave) from the 60s and the early 70s revealed the dark sides of Yugoslav socialism, which were ignored by the official ideology; however, it is hard to draw an aesthetic parallel between crni talas and the recent bh. cinema. 
Žalica is one of the many who bring accusations also against the international community, which is keeping the new Bosnian order in custody. The topos of Western soldier willingly using the services of brothels is often present in the latest bh. cinema and draws attention to their dubious contribution to restoring a stable, conflict-free everyday life. In the eyes of the artists, $\mathrm{BiH}$ seems to be an exploited plaything in the hands of the West, which gives permission for the undisturbed local increase in crime.

Another aspect of the broad interrelationship between the local authorities and the criminal world got its fuller realization in Srđan Vuletić's Summer in the Golden Valley (2003). The director, telling the story of Ramiz who, working as a police officer is simultaneously involved in the criminal world of Sarajevo, exposes the hypocrisy of the government authorities. Paradoxically, the police seem to be the main threat to citizens, instead of protecting them. Vuletić offers an uncompromising criticism of cynical government policy which accepts the situation when a criminal acts as the main guardian of public order. In the eyes of the society, the state is completely disgraced - when on the flagpole, instead of the blue-and-yellow $\mathrm{BiH}$ state flag, a pair of old, worn-out pants are seen flapping about. The state symbols are also taunted by other artists - the main character of Faruk Sokolović's Mliječni put (The Milky Way, 2000) speaks his mind about the national anthem of $\mathrm{BiH}$. He considers the attempts of his daughter, trying to learn to play the anthem, useless - after all, the anthems change every now and then.

The thoughtlessness and social insensitivity of the authorities are exposed by Jasmila Žbanić in Grbavica (Grbavica: the land of my dreams, 2006). The situation in which financial support from the State can be granted only to the children of fallen war heroes is an emphatic criticism of the Bosnian transition. The institutional framework of the post-war State is incessantly defined by the ethnonationalist divisions from the time of war. Thus, the State marginalizes and stigmatizes all those people who are insufficiently "honoured". Paradoxically, these rules most harm two women in great need of urgent social assistance: Esma, the main character of the film, raped during the war by a Serbian soldier, and her daughter Sara, the unwanted fruit of this violence. The inefficient state institutions are incapable of providing either economic or symbolic support to the forgotten victims. On the contrary, they generally tend to be oppressive towards the most deprived citizens.

Aida Begić, the director of Djeca (Children of Sarajevo, 2012), has gone deeper into this issue, minutely portraying the dramatic situation of the young generation - Sarajevian orphans whose fathers shed their blood for 
the freedom of the city. The major threat to Rahima, the main character of the film, are the visits of the social welfare assistant. Although Rahima took her younger brother, Nedim, away from the orphanage to look after him, the arrogant and indifferent woman baselessly accuses her of incompetence and lack of commitment. Neither the curator, nor Nedim's school teacher, try to see Rahima's huge commitment to make her brother feel loved and secure. Moreover, Rahima's direct confrontation with a local politician also ends up in humiliation. The main character, forced to ask the wealthy government official to postpone Nedim's debt repayment, resembles a beggar seeking favour with the king. In such a situation, the politician turns out to be a sordid bastard, making her a sexual proposal as a form of debt repayment.

According to the authors, the extreme egoism of the political elites is responsible for the ongoing structural breakdown of the $\mathrm{BiH}$ society. The political authorities are alienated from society and entirely focused on satisfying their perverse fantasies. Benjamin Filipović in Dobro štimani mrtvaci (Well-tempered corpses, 2005) points directly at the narcissism of the government representatives, creating the character of a self-interested Minister of an unspecified department, who provokes everyone with her vulgar eroticism. The corrupt state official is to be an expressive metaphor for a depraved spectacle of power, devoid of essence and played only for the vain satisfaction of its few participants. The scene, in which the Minister masturbates in the office, watching replays of her own speeches made in Parliament, illustrates it best. The authorities seem to be delighted with themselves to such an extent that they are totally blind to the on-going, complex, social tragedy, thus condemning almost every social class to fail. This point of view is also shared by Antonio Nuhić, who in Sve džaba (2006) criticizes the reckless and chaotic actions consistently being taken by the authorities. In Nuhić's film even a random passer-by knows that Bosna i Hercegovina je država koja umire ${ }^{7}$.

All the filmmakers of the recent bh. cinema unanimously agree that the political authorities, not executing their basic duties, have long since abandoned their own society. They seem to be saying that the society has to get by on its own.

\section{Trying to keep afloat}

Social criticism of the recent bh. cinema can, therefore, be read as a collective, multi-layered story about various attempts to deal with the provisional reality of the never-ending transition. The characters are forced

Eng. Bosna and Herzegovina is a dying country; [Sve džaba, 00:46:16]; all translations in the text - TR. 
to face the fragile present that is irrevocably devoid of stable reference points, such as permanent jobs, decent housing conditions or wages high enough to survive the next month. Living in a constant danger of loss limits their existence to the fight for economic survival. The critical bh. cinema does not actually talk about dreams, goals or aspirations and only occasionally mentions values ${ }^{8}$. Instead, it tells the story of survival strategies.

The déclassé heroes of Mliječni put and Grbavica are forced to take odd jobs as manual workers. Mujo, a former professor of biology, works as a buckboard driver - dressed in a folk costume, he drives around Sarajevo, carrying Western tourists fascinated by the post-war landscape of the destroyed city. His wife, in turn, works as a door-to-door saleswoman of vacuum cleaners. Esma from Grbavica, a former student of medicine, works as a waitress in a nightclub. Despite performing hard and uphill manual labour, the film characters never get the opportunity to satisfy their basic needs.

Rahima from Djeca also works as a poorly paid kitchen help. Aida Begić emphasizes the problem of the lost post-war generation, bogged down in alcoholism and drug addiction. The main heroine of the film is one of the few among them who managed to get out of the hell of addiction. However, the director throws doubt on her personal heroic struggle, using Rahima as an example to show that the young generation will not get a chance to build a better future for $\mathrm{BiH}$ - for it will never, regardless of its efforts, get out of the overwhelming trap of everyday life.

In its radical version, the strategy of temporary survival brings some bh. cinema characters to desperate attempts of trading in their own war trauma. One of the background stories of Mliječni put is the story of a man who sells the soil from the local minefield to Western tourists. The tragic awareness that only making a public event of a personal disaster may help improve the situation, pushes also the heroes of Ognjen Sviličićs s9 Armin (2007) into participating in the casting for a West European film about the Bosnian war.

The Bosnian transition is permanently marked by the figure of a disabled man, deprived of, at least, one of his limbs. The figure of a handicapped person, present in many film texts, represents, on the one hand, the magnitude of the tragedy that struck $\mathrm{BiH}$, and, on the other, the badly damaged society that is incapable of independent functioning.

\footnotetext{
8 The issue of the so-called higher values, above all a deep religious commitment, is particularly visible in the films of Aida Begić - especially in Snow (2008) and, to a lesser extent, in Children of Sarajevo (2012).

9 Ognjen Sviličić is a Croatian film director who, however, succeeded perhaps the most in the whole recent bh. cinema, in sketching the portrait of a stigmatized Bosnian provincial.
} 
Few bh. cinema characters see the transition as an opportunity to find their own way in the bothersome present. The most interesting metaphor for the small business initiative, emerging in pain to fund the new Bosnian capitalism, is the self-proclaimed president of the grotesque transport company "Kučuk railways" from Dobro uštimani mrtvaci. The comical Ruždija Kučuk wants to privatize the railroad track Vranduk-Sarajevo, for he carries passengers in his improvised vehicle there. The director, however, condemns Ruždija to a repeated coma that resembles clinical death, making bystanders sure that the railwayman is dead. It is a straightforward diagnosis of the desperate condition of the Bosnian economy which cannot develop fluently, consistently being doomed to failure by everyone. Although Filipović deeply believes in the perseverance and tirelessness of the Bosnian businessman (Ruždija Kučuk is the only one to survive until the end of the story), his failure seems to be inevitable. Unfortunately, the only beneficiaries of the Bosnian transition are the former criminals who turned into managers of the nightclubs (appearing in Grbavica) and those owners of local businesses who do not hesitate to ruthlessly eliminate their competition (such as Ljubo from Sve džaba or Ale from Mliječni put). Nothing indicates that this could change.

\section{There is nothing more, but an escape}

In the recent bh. cinema, each and every strategy that assumes an independent, persistent and legal struggle with difficulties is doomed to failure. The total lack of perspectives for any positive change within the inefficient system often results in not taking the demanding and unrewarding strategy of temporary survival at all. Above all, the bh. cinema characters choose to escape into a different reality.

The world of crime is one of the most frequently chosen alternatives. It is never difficult to jump into it, after all it is ubiquitous and it functions in symbiosis with legal reality. The artists harmoniously indicate that the underworld is a particularly tempting alternative for the youngest generation. Indifferent Nedim, a Sarajevo orphan, gets caught up in the criminal world very easily. By contrasting him with the heroic, hardworking sister, Aida Begić exposes a simple pattern of the Bosnian transition - the only choice one can make is the choice between humiliating and devastating work for criminals and joining them. The same thing happens with Fikret, a teenager from Ljeto u zlatnoj dolini, who gets involved in criminal activity, seeing no other options. After his father's death, Fikret is burdened with the responsibility of paying off his father's debts. He can rise to this challenge only by taking part in kidnapping the daughter of a wealthy businessman. 
A child with a gun in his hand is one of the most common topoi of the recent bh. cinema. It is an expressive metaphor for the deep trauma of war which falls on the young generation. By putting together the innocence of a child and the violence of a gun, the artists make one of the most serious accusations - the accusation against the ubiquitous social permission to reproduce fear, aggression and moral nihilism. In this context, the words spoken by Fikret and his closest friend: Nikad nismo bili ni na moru. Zato znamo sve o pištoljima, puškama, granatama $(\ldots)^{10}$, sound like a manifesto of the lost generation, although they are kept in an action-film parody convention.

Some filmmakers, particularly those who make popular cinema, try to tame the world of crime by creating harmless and comical thugs. In Pjer Žalica's Gori Vatra, criminals are an integral part of the local environment. They take part in all local events and are also involved in the preparations for the arrival of the President of the United States. The friendly gangster Ale from Mliječni put not only creates job vacancies in the sporting goods store he owns, but also financially supports the main film heroes and willingly helps them realize their plan to flee the country. In the inverted Bosnian reality, the figure of a tamed thug seems to be a substitute for the alienated elites. A good bandit is the only person to whom the dominated society can turn for help and even receive it - often gratuitously or in exchange for a small favour.

Critically oriented artists agree that the underworld works almost on equal rights with the legal world. In that case, there remains the question of whether jumping into the world of crime must always be treated as an escape?

Such concerns do not apply to those characters who decide to leave the country. The strategy of emigration is a radical form of escape from the harsh reality. They all run. Mujo and Sena from Mliječni put, the married couple from Sarajevo, dream of going to New Zealand. The distant, unknown and uncertain country, appears to them as the Promised Land. The main obstacle again proves to be the ridiculous law, this time set by the international administration in $\mathrm{BiH}$, which gives permission to leave only to ethnically mixed marriages. Although Mujo and Sena's struggle to get out of the country at all costs is kept in a comedy convention, the film shows that in contemporary $\mathrm{BiH}$ one can achieve one's goals either by intentionally bypassing the law or submitting to its absurdity. Finally, two couples, déclassé Muslim intellectuals and young Bosnian Croats, make a fictional exchange of their partners, formally contracting two ethnically

10 Eng. We have never been to the sea yet. We know everything about pistols, rifles and grenades, instead [Ljeto u zlatnoj dolini. 00:32:32]. 
mixed marriages. Only then do they get permission to leave. Furthermore, the originator of the whole project is the aforementioned good bandit Ale.

The Bosnian province also keeps trying to emigrate. The father of teenage Armin, in search of a better future for his son, takes him to Zagreb to take part in a casting for a war movie about $\mathrm{BiH}$. The travel to Croatia is a symbolic attempt to save the child from the stigma of the Bosnian provincial. Although Armin's father believes that announcing his son's existence to the people from the "better world" would at last pull him out of a hopeless situation, he ends up terribly disappointed. The Western saviours turn out to be just another bunch of instrumental hunters of emotions. Moreover, the main characters cannot afford the price they demand for Armin's social promotion. Armin and his father reject the proposal of emotional exhibitionism in front of the camera, but they pay dearly for such a moral victory - they have to return to their home village after just a momentary visit in a better reality.

Even those citizens who voluntarily returned from Western Europe to $\mathrm{BiH}$, dream of an immediate re-emigration. Risto, the gay-architect from Dobro uštimani mrtvaci, is humiliated because of his sexual orientation at every step. By contrast, his partner Mario, a personal assistant of the aforementioned calculated Minister, is constantly being forced to take part in her political deceptions. Both gay men are metaphors of a tethered freedom, stifled by the corrupt political elites on the one hand and crushed by the primitive and, in the director's opinion, immature society, on the other. Risto's artistic sensibility becomes totally destroyed in a flash - he loses his job, the rented apartment and a relatively high social position. Finally, the director does not let him go back to his beloved Amsterdam - his accidental death is an overwhelming accusation against the cruel Bosnian reality that ruthlessly destroys any individuality.

One of the characters from Mliječni put says that Svi odlaze, samo mi (pensioners - TR) $i$ Kinezi ostajemo ${ }^{11}$. On the contrary, the majority of people do not decide to leave. Those who choose to stay, or just cannot leave for some reasons, usually embark on an inner emigration, often remaining immersed in nostalgia for the pre-war past. The time of Yugoslav brotherhood and unity is still the whole life of Stjepan from Mliječni put, the aged teacher and dedicated communist. In his final appearance, the old "comrade" refuses to put a big portrait of Josip Broz Tito in the hold of the plane bound for New Zealand as he considers it an act of insult. Similarly, professor Mujo finds the only relief in the provisional greenhouse he calls Kuća cveća ${ }^{12}$. Finally, the director destroys Mujo's Kuća cveća, clearly

11 Eng. Everybody is going away, only the Chinese and us are not [The Milky Way, 1:17:22].

${ }_{12}$ Kuća cveća/cvijeća (House of Flowers) - Josip Broz Tito’s mausoleum located in Belgrade. 
suggesting that the time of idealized socialist welfare has to pass away, regardless of the characters' will.

In addition, Kuća cveća is covered with a protective foil the international community used during the war to build temporary shelters for $\mathrm{BiH}$ refugees. The foil marked with the $\mathrm{UNHCR}^{13}$ logo is a repeated motif, another symbolic accusation against the West. The protective UN foil never protects - in the crucial moment it is always torn by the wind or destroyed by bulldozers. Thus, the artists suggest that the new Bosnian order, allegedly provided by the international community is, in fact, fake and unstable.

Teenage children, who cannot hide in the fortress of yugonostalgy, for their first memories date back to the war time, are forced to flee into their own imagination or virtual reality. Fikret, the main character of Ljeto $u$ zlatnoj dolini is endowed with an impressive imagination - a rare feature among apathetic Bosnian youth. Apart from taking drugs and being involved in criminal business, he makes up stories styled upon the Far East legends, thus creating a substitute for a better reality. Also Nedim from Djeca drifts between the virtual reality of the TV or computer screen and the harsh reality of theft and criminal activity. Both seem to be oblivious to anything in between.

Sometimes, the desolate society chooses to jump into utopia. The film characters' helplessness pushes them to desperately believe that they are able to realise even extremely unrealistic projects alone, with no help from the outside. The most expressive dreamer is a lower-class pensioner from Dobro ustimani mrtvaci, firmly convinced that he will revolutionize the world's aeronautical engineering thanks to the oil-powered aeroplane he independently designed in his basement. The essence of this tragicomic situation is his motivation - he just wants to fly over the Atlantic Ocean to visit the daughter he has not seen for years. Moreover, the amateur engineer, who cannot afford the plane ticket to the United States, also takes on the role of a social activist - his revolutionary aeroplane is to serve the common good. However, thousands of people in a similar situation will not have the opportunity to use it - the project, consistently ignored by the politicians, results in a terrible plane crash. The pensioner dies a tragic death. Bosnian utopias of a more egalitarian social reality tend to end up in spectacular failure.

When the total lack of prospects turns life into a slow vegetation, devoid of any hope, there is often no place to run. The artists unanimously emphasize an instant, overwhelming sense of insecurity - one should be prepared for a material, social or emotional loss at any time. Some people

13 UNHCR - The Office of the United Nations High Commissioner for Refugees. 
lose everything, like Goran, the main character of Sve džaba, whose family was taken by the war. During the post-war period of constant uncertainty he loses a group of old friends, with whom he got drunk to unconsciousness every night. Together with their death during a gunfight at a local bar, Goran loses what is left of his feeling of delusive safety, which was anyway based on the collective sliding into mute despair. Socially uprooted Goran definitively falls into a terrifying loneliness he is unable to cope with.

For Goran, the only possible strategy of escape from such an extreme situation, appears to be passive floating with the stream of random events. $\mathrm{He}$ drifts aimlessly around the country in an old truck converted into a mobile bar, serving free drinks to the people he accidentally meets. Thus, he gets rid of the last money he earned from the sale of an inherited house. Goran surrendered - he irrevocably lost his last hope for any positive life change and became totally indifferent to the future. The potential of social integration based on the common good, suggested by Nuić but, unfortunately, understated in the film, has no chance of realization as well. The director seems to be convinced that the people of $\mathrm{BiH}$ do not understand the concept of social trust any more.

\section{Conclusions}

The recent bh. cinema talks about the peripheries of life. The discussed films present an alarming vision of the $\mathrm{BiH}$ society during the period of transition. The society is radically distant from the political and economic elites which are, in turn, socially insensitive, totally self-centred and widely connected with the criminal world. The heroes of the bh. cinema, forced to survive in an extremely oppressive reality, do not identify with their own country. Sometimes, they are enclosed in small enclaves based on local social bonds (always fragile and constantly threatened with a breakdown), but more often they seem to be alienated from the society. The BiH society is devoid of subjectivity and the moving spirit. In its desperate attempts to deal with the reality, it has no opportunity to go beyond the fruitless strategies of temporary survival. In contemporary $\mathrm{BiH}$, which still carries the tragic burden of war, there are no positive solutions.

The only action one can take, hoping for an improvement in the situation, is to escape from the reality. The few who will manage to escape indeed will fulfil their dreams of emigration. The vast majority, however, will remain in the trap of the absurdities of everyday life. They will search for a symbolic escape, always ephemeral and illusory. The recent bh. cinema, dominated by stories about the strategies of avoiding participation in the reality, can be seen as the cinema of escapism, giving an account of the diverse escape 
strategies into an alternate reality - the nostalgic past, the imagined present or the utopian future ${ }^{14}$.

Social criticism in recent bh. cinema is mostly limited to showing a detailed picture of the enormous tragedy of the Bosnian transition. Although all the filmmakers seem to be socially engaged artists, their ideological stand is often blurred. In the recent bh. cinema, "the scoffers' lodge", which offers a devastating critique of each element of the Bosnian reality, seems to dominate. Such artists as Srđan Vuletić, Antonio Nuhić, Faruk Sokolović, and above all, Benjamin Filipović, not only criticize the ruling elite, but also ruthlessly judge the society itself (although they see its weakness). In Sve džaba, Antonio Nuhić accuses it of extreme egoism, rowdiness and xenophobia, that emerge in the world of stuffy and tight social bonds. Benjamin Filipović in Dobro uštimani mrtvaci scoffs at its general insensitivity, intolerance and being ruled by animal instincts. On the other hand, Srđan Vuletić's advice for the younger generation, even though, in Ljeto u zlatnoj dolini he tries to avoid commenting, is, in fact, to hide in privacy - which means, paradoxically, to continue the current strategies of escape.

Pjer Žalica from Gori Vatra falls into "the scoffers' lodge" only partially, for he proposes a complex vision of the $\mathrm{BiH}$ society - a local microcosm turned into chaos by the hurricane of war. Žalica's stand is not convincing, though. His suggestion, that cutting off politics from social life and letting ordinary people resolve all the problems alone would lead to a spontaneous mutual reconciliation, is too naively optimistic.

Members of "the scoffers' lodge", on the one hand try to make critical films, but, on the other, actually seem not to be looking for any solutions. They seem to remain suspended in a specific void - within the popular cinema they have the opportunity to avoid total commitment, but simultaneously they cannot reproduce the dominant discourse, that appears to be one of the main features of popular cinema (Helman 2007: 266). Such reproducing seems to be almost impossible, for the fuzzy state policy neither makes credible promises of a better tomorrow, nor proposes any joint vision of the future. Perhaps, as a result of this duality, social criticism of "the scoffers' lodge" is a smashing criticism of everything, a criticism of the artists gone astray. They seem to be astray to the same extent as the whole society.

It seems that only the work of Aida Begić and Jasmila Žbanić should be called an engaged social criticism. However, one can find them at opposite ideological poles. The author of Grbavica and Na putu consistently tries

\footnotetext{
14 The cinema of escapism, understood this way, should be distinguished from the escapist cinema; the authors of the escapist cinema deliberately avoid undertaking difficult social issues by choosing, for instance, existentialist topics.
} 
to act as a spokesman for defence of pro-European-oriented elites of the Federation of BiH. Grbavica, irrespective of its valuable criticism of the inefficient state institutions, is made around the metaphor of $\mathrm{BiH}$ as an innocent victim ruthlessly abused by an evil invader. Then, Na putu, makes the spectator believe that $\mathrm{BiH}$ has its own liberal middle class which has already grown up to the standards of Western democracy. However, the basic problem of $\mathrm{Na}$ putu is that the film does not represent almost anyone - the well-off young people portrayed by Žbanić are still hardly present in the population of $\mathrm{BiH}$.

The attitude of Aida Begić, a representative of socially engaged cinema focused mainly on women, seems to be pro-social to the highest degree. Her films are not only critical, but also point at the possible ways of helping the damaged society. She indicates the specific defects of the welfare system and the crucial importance of social solidarity. Begić, particularly in Djeca, courageously and consistently stands up for their rights and supports the people who are being marginalized. After all, they constitute the majority of the Bosnian society.

\section{References}

Helman Alicja (2007). Krytyka ideologiczna, in: Helman A., Ostaszewski J. (eds.), Historia myśli filmowej. Podręcznik. Gdańsk: 261-279.

Ibrahimović Nedžad (2008). "Između naracije i kreacije (bosanskohercegovački igrani film 1995 - 2008)", Sarajevske sveske, 19-20: 116-165.

Pavičić Jurica (2008). "Pregled razvoja postjugoslavenskih kinematografija”, Sarajevske sveske, 21-22: 643-675.

\section{Filmography}

Mliječni put (The Milky Way), director: Faruk Sokolović; screenplay: Almir Imsirević, Edina Kamenica, Faruk Sokolović; cast: Selma Alispahić, Dragan Bjelogrlić, Nada Djurevska, et al.; produced in: Bosnia and Herzegovina year of production: 2000; length: $93 \mathrm{~min}$.

Ljeto u zlatnoj dolini (The Summer in the Golden Valley), director and screenplay: Srđan Vuletić; cast: Haris Sijarić, Svetozar Cvetković, Emir Hadžihafizbegović, et. al.; produced in: Bosnia and Herzegovina, France, Great Britain, Slovenia; year of production: 2003; length: $105 \mathrm{~min}$.

Gori vatra (Fuse), director: Pjer Žalica; screenplay: Ahmed Imamović, Pjer Žalica; cast: Enis Bešlagić, Senad Bašić, Jasna Žalica, et. al.; produced in: Bosnia and Herzegovina, Austria, France, Turkey; year of production: 2003; length: 105 min.

Dobro uštimani mrtvaci (Well-tempered Corpses), director: Benjamin Filipović; screenplay: Benjamin Filipović, Fedja Isović; cast: Lazar Ristovski, Irena Micijević, Emir Hadžihafizbegović, et. al.; produced in: Bosnia and Herzegovina, France, Italy, Slovenia; year of production: 2005; length: $92 \mathrm{~min}$. 
Grbavica (Grbavica: the Land of my Dreams), director and screenplay: Jasmila Žbanić; cast: Mirjana Karanović, Luna Mijović, Leon Lučev, et. al.; produced in: Bosnia and Herzegovina, Austria, Croatia, Germany; year of production: 2006; length: $90 \mathrm{~min}$.

Sve džaba (All for free), director and screenplay: Antonio Nuić; cast: Enis Bešlagić, Nataša Janjić, Bogdan Diklić, et. al.; produced in: Bosnia and Herzegovina, Serbia and Montenegro, Croatia; year of production: 2006; length: 94 min.

Armin (Armin), director and screenplay: Ognjen Sviličić; cast: Armin Omerović, Emir Hadžihafizbegović, Daria Lorenci, et. al.; produced in: Croatia, Bosnia and Herzegovina, Germany; year of production: 2007; length: $82 \mathrm{~min}$.

Snijeg (Snow), director and screenplay: Aida Begić; cast: Zana Marjanović, Jasna Beri, Vesna Mašić, et. al.; produced in: Bosnia and Herzegovina, France, Iran, Germany; year of production: 2008; length: $100 \mathrm{~min}$.

Gori vatra (Fuse), director: Pjer Žalica; screenplay: Ahmed Imamović, Pjer Žalica; cast: Enis Bešlagić, Senad Bašić, Jasna Žalica, et. al.; produced in: Bosnia and Herzegovina, Austria, France, Turkey; year of production: 2003; length: 105 min.

Na putu (On the Path), director and screenplay: Jasmila Žbanić; cast: Zrinka Cvitešić, Leon Lučev, Ermin Bravo, et al.; produced in: Bosnia and Herzegovina, Austria, Croatia, Germany; year of production: 2010; length: $100 \mathrm{~min}$.

Djeca (Children of Sarajevo), director and screenplay: Aida Begić; cast: Marija Pikić, Ismir Gagula, Nikola Djuricko, et. al.; produced in: Bosnia and Herzegovina, France, Germany, Turkey; year of production: 2012; length: $90 \mathrm{~min}$.

\section{Jak uciec? \\ Pułapka transformacji w najnowszym kinie Bośni i Hercegowiny (2000-2012)}

Tekst dotyczy najnowszej kinematografii Bośni i Hercegowiny (2000-2012). Skupienie na nurcie kina krytycznego (do którego zaliczone zostały filmy, które próbują interpretować nowy porządek społeczno-polityczny powoli wyłaniający się w Bośni i Hercegowinie po wojnie z lat 1992-95) pozwala ukazać społeczeństwo Bośni i Hercegowiny jako znajdujące się w pułapce wciąż niedokończonej transformacji systemowej. Opowieść o społeczeństwie z jednej strony uwięzionym w dysfunkcjonalnym i opresyjnym państwie, a $\mathrm{z}$ drugiej całkowicie pozbawionym perspektyw i nadziei na poprawę sytuacji, zdominowana jest przez rozmaite strategie ucieczki w alternatywną rzeczywistość: nostalgiczną przeszłość, wyobrażoną teraźniejszość lub utopijną przyszłość. W tym sensie, bośniackie kino krytyczne jawi się jako kino eskapizmu społecznego. 